\title{
Prevalence of HCV Antibodies in Chronic Liver Disease Patients in Tertiary Care Hospital
}

\author{
Aliya Fatima* and K. Nagamani \\ Department of Microbiology, Gandhi Medical College \& Hospital, Secunderabad, \\ Telangana, India \\ *Corresponding author
}

A B S T R A C T

\begin{abstract}
\begin{tabular}{|c|}
\hline $\begin{array}{l}\text { Ke y w o r d s } \\
\text { CLD, HCV }\end{array}$ \\
\hline Article Info \\
\hline $\begin{array}{l}\text { Accepted: } \\
\text { 10 September } 2018 \\
\text { Available Online: } \\
10 \text { October } 2018\end{array}$ \\
\hline
\end{tabular}
Viral infections account for significant proportion of CLD. Hepatitis C virus is the major cause of non-A, non-B hepatitis worldwide. HCV can lead to chronic liver disease causing cirrhosis, hepatocellular carcinoma and end stage liver disease among 5-20\% of infected persons. In India about 20 million people are known to have HCV infection and a quarter of them are expected to develop chronic liver disease in the next 10-15 years. 1) To determine prevalence of Hepatitis $C$ virus infection in chronic liver disease patients. 2) To identify the risk factor for HCV infection. A total of 100 Cases of CLD attending Gastroenterology department were included in the study during the period of January 2015 - June 2016. Demographic data and clinical findings were recorded using a structured proforma. All the samples were screened for anti HCV antibodies by ELISA (HCV MICROLISA) according to the kit manufacturer's instructions. Out of 100 CLD Patients, $81(81 \%)$ were Males and $19(19 \%)$ were Females. HCV antibodies were found positive in 4 cases. Out of 4 cases, 3 were Males and 1 was Female. Prevalence of HCV in CLD Patients was $4 \%$. The major risk factor for HCV Infection was Surgery.
\end{abstract}

\section{Introduction}

Chronic liver disease (CLD) is a disease of the liver resulting from an inflammation due to infiltrative, immunological, mechanical or metabolic injury to the liver, which has persisted for six or more months without complete resolution (Laraba et al., 2009)

Viral infections account for significant proportion of CLD. Hepatitis B and Hepatitis $\mathrm{C}$ viruses account for $75 \%$ of all cases of liver disease around the world (Nirmala Poddar et al., 2012). WHO estimates 170-200 million people are chronically infected with $\mathrm{HCV}$ worldwide (Hanaa Ali Naem and Hassan J. Hasony, 2015). HCV can lead to chronic liver disease causing cirrhosis, hepatocellular carcinoma and end stage liver disease among 5-20\% of infected persons (Nirmala Poddar et al., 2012). In India about 20 million people are known to have $\mathrm{HCV}$ infection and a quarter of them expected to develop chronic liver disease in the next 10-15 years. The impact of this infection has started to emerge in India (Ramya and Madhuri Kulkarni, 2015). It is the major cause of non-A, non-B hepatitis (Vardas et al., 1999). 
$\mathrm{HCV}$ is a small, spherical, enveloped RNA virus that encloses a long, single-stranded, positive sense genomic RNA with an icosahedral capsid.

The prevalence of chronic HCV ranges from $0.1 \%$ to $5 \%$ in different countries (Laraba et al., 2009).

HCV seroprevalence reported in South India is $0.22 \%, 0.3 \%$ in Western India, $1.8 \%$ in Central India and $1.9 \%$ in North India (Ramya and Madhuri Kulkarni, 2015) (Table 1).

$\mathrm{HCV}$ is transmitted primarily through blood or blood products or contact with infected tissue (blood transfusion, intravenous immunoglobulins, intravenous drug abuse and tissue transplantation).

Others route of $\mathrm{HCV}$ transmission have also been implicated like sexual, vertical and household contacts (Vardas et al., 1999)

No effective vaccine has been developed to prevent HCV infection (Yao et al., 2005). The high genomic heterogeneity of $\mathrm{HCV}$ may contribute to viral immune evasion, promote chronicity and may influence the outcome of interferon $\alpha$ therapy in HCV- infected individuals (Yao et al., 2005). The genome of $\mathrm{HCV}$ is highly mutable.

The mutation occurs in hyper variable region of the genome coding for the envelope proteins and escapes immunity by the host and at the same time knocks host's innate immunity resulting in $\mathrm{HCV}$ chronic infection

\section{Materials and Methods}

Study design: Cross-sectional Descriptive study

Study period: 18 months (January 2015 -June 2016)

\section{Inclusion criteria}

The Chronic liver disease patients of all age groups and both the sexes attending Gastroenterology unit in Gandhi Hospital.

\section{Exclusion criteria}

Chronic liver disease secondary to metabolic diseases.

Sample size: 100

\section{Sample collection}

Approval of Institution ethical committee was obtained to carry out the study. Patients were enrolled in the study after obtaining consent epidemiological and clinical data was recorded using a structured proforma.

About $2 \mathrm{ml}$ of blood was collected under aseptic conditions. All the samples were screened for anti-HCV antibodies using third generation ELISA. The procedure was strictly followed according to the kit manufacturer's instructions. Test specimens with absorbance value less than the cut-off are considered nonreactive for anti-HCV. Test specimens with absorbance value greater than or equal to the cut-off value are considered reactive for Anti$\mathrm{HCV}$ antibodies.

\section{Results and Discussion}

100 Patients with chronic liver disease admitted in Gastroenterology unit of Gandhi Hospital were included in the study.

Males 81 and Females 19 (Fig. 1)

Male to Female ratio of the total chronic liver disease patients $4.2: 1$

In present study, most of the cases belong to the age group 41-50 years (Table 3, Fig. 2). 
In Present study, Out of $4 \mathrm{HCV}$ positive cases, 3 were males and 1 was Female (Fig. 3).

Most of the HCV positive cases belong to 4060 Yrs of age group (Fig. 4).

In Present Study, Surgery is a major risk factor for $\mathrm{HCV}$ infection in Chronic liver disease cases. In Present study, Prevalence of Hepatitis $\mathrm{C}$ in Chronic liver disease patients was $4 \%$ similar to reports from India by (Arora et al., 2005), (Sanjay Sharma et al., 2016).

In Present study, Males (75\%) were more commonly affected than females $(25 \%)$

Similar observations were made by several authors from India and Pakistan as shown in Table 2.

Fig.1 Gender wise distribution of chronic liver disease cases included in the study

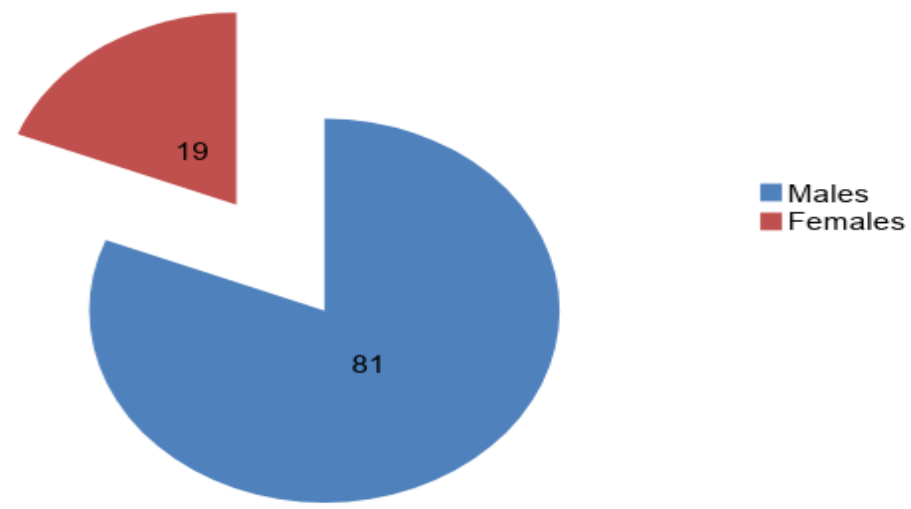

Fig.2 Age and sex wise distribution $(n=100)$ Patients included in the study

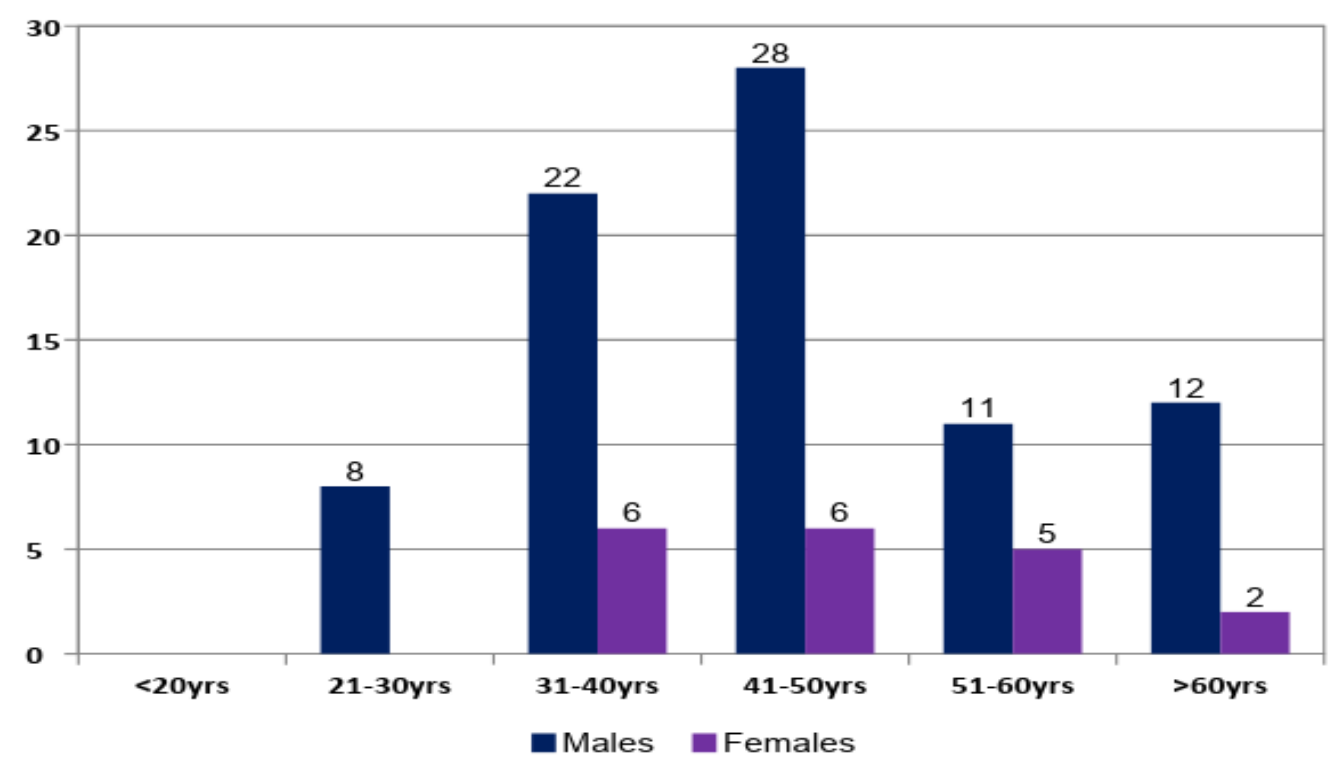


Fig.3 Comparison of HCV positive and negative patients in chronic liver disease with regard to gender

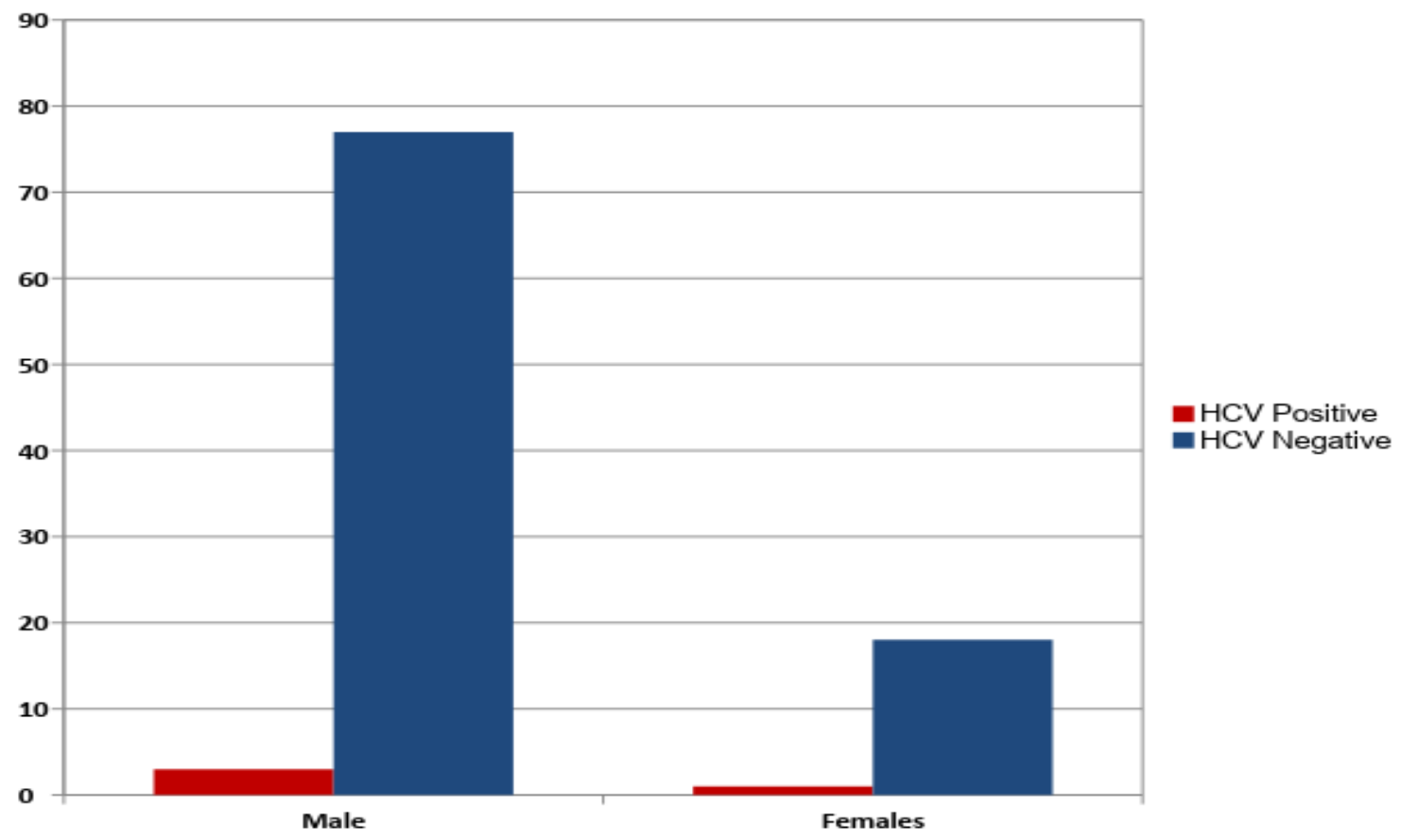

Fig.4 Prevalence of HCV in different age groups

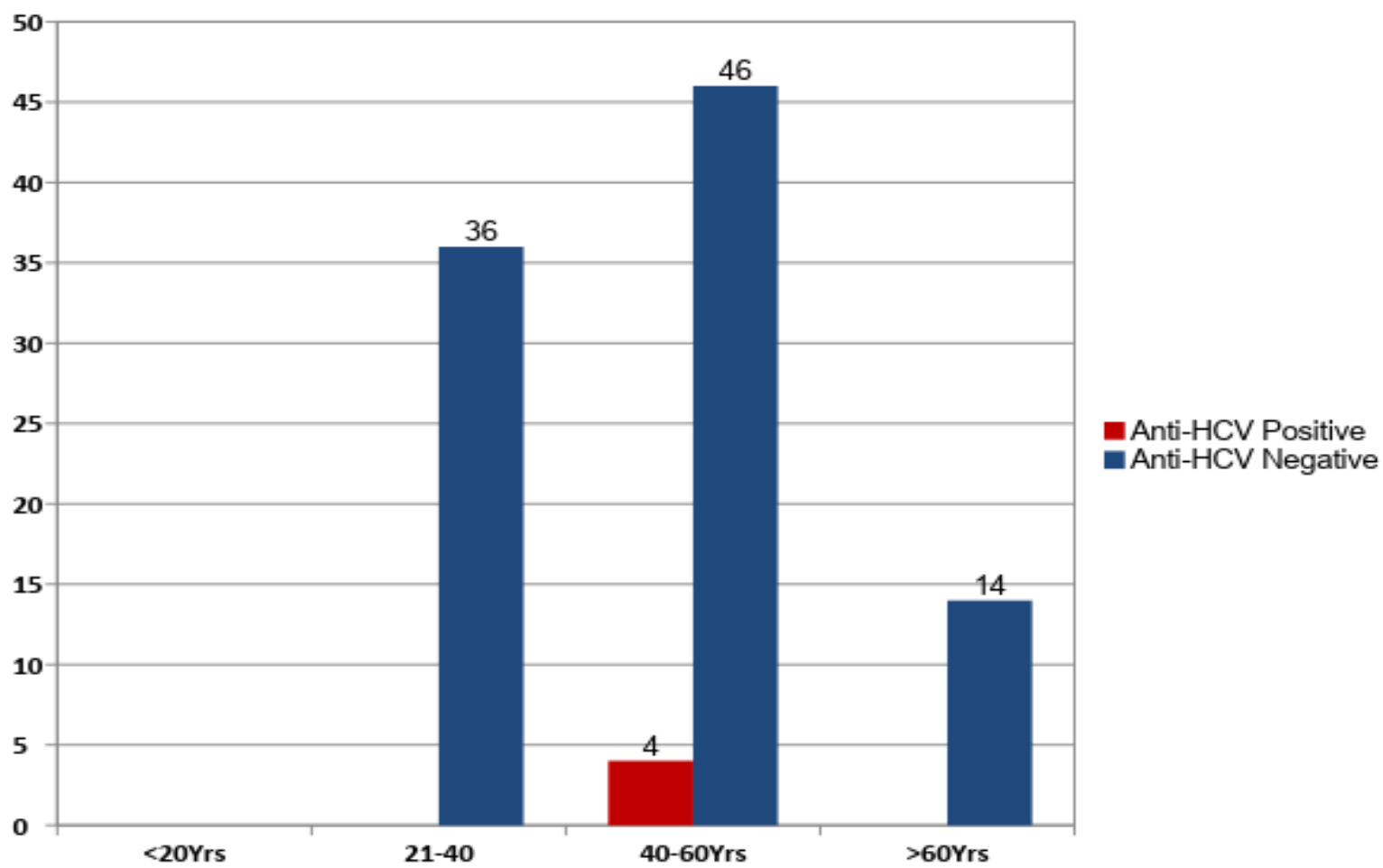


Fig.5 Risk factors among HCV Positive and HCV negative cases

\section{Risk factors among HCV Positive and HCV Negative} cases

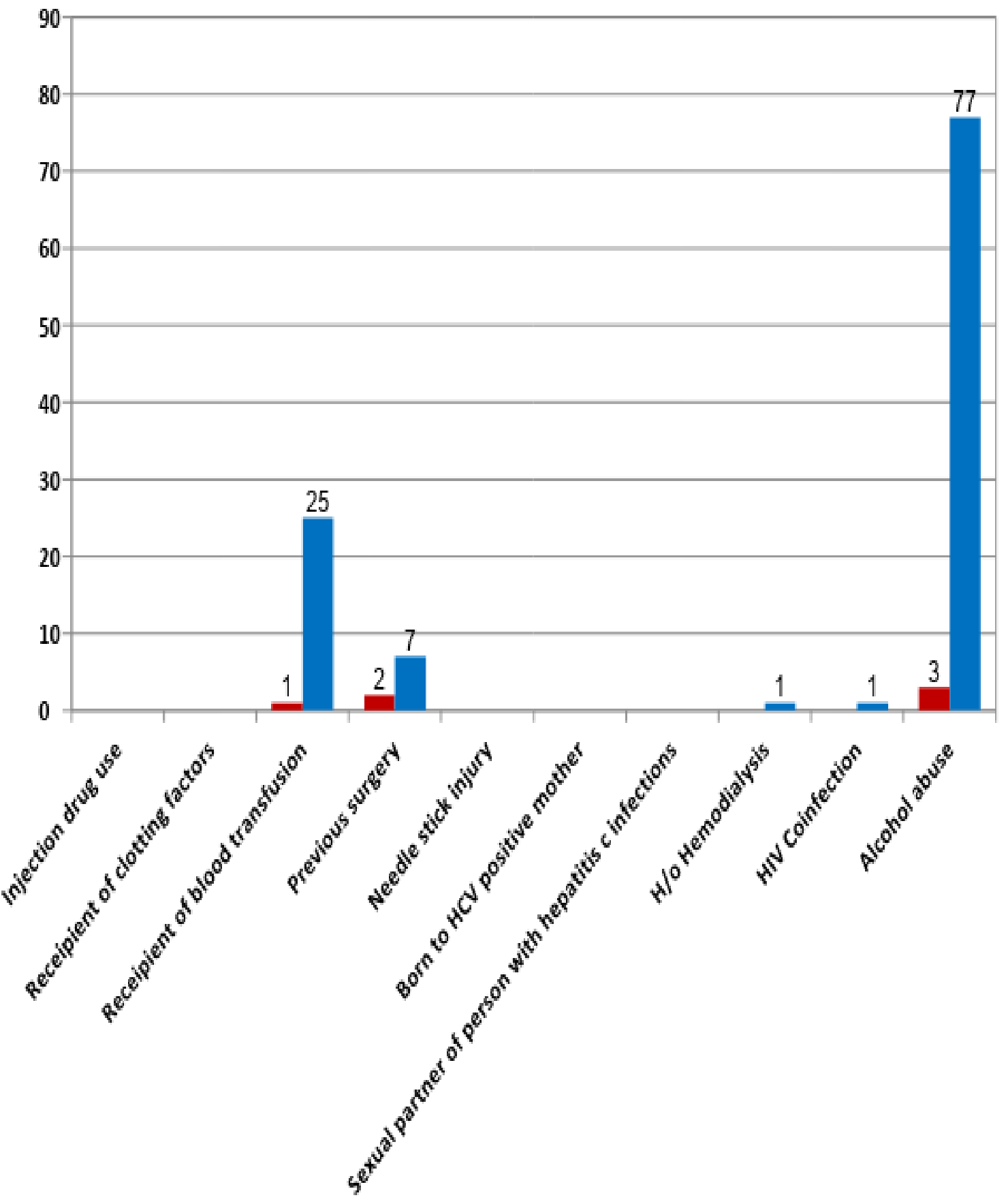

nCV Positive cases $\quad$ HCV Negative cases 
Table.1 Prevalence of hepatitis $\mathrm{c}$ in chronic liver disease

\begin{tabular}{|c|c|c|c|c|}
\hline S. No & Author & Place & Year & Prevalence \\
\hline 1. & Chen et al., & Taiwan & 1990 & $43 \%$ \\
\hline 2. & Colombo et al., & Italy & 1991 & $74 \%$ \\
\hline 3. & Tandon et al., & North India & 1991 & $42 \%$ \\
\hline 4. & Amarapurkar et al., & Bombay & 1992 & $15-20 \%$ \\
\hline 5. & Khuroo et al., & Kashmir & 1993 & $26 \%$ \\
\hline 6. & Sumathy et al., & South India & 1993 & $23.9 \%$ \\
\hline 7 & Sarin et al., & North India & 1996 & $10.8 \%$ \\
\hline 8 & Chatterjee et al., & Calcutta & 2001 & $8.06 \%$ \\
\hline 9 & Arora et al., & India(Haryana) & 2005 & $4.28 \%$ \\
\hline 10 & A.Laraba et al., & Nigeria & 2009 & $14.4 \%$ \\
\hline 11 & Abel Girma Ayele et al., & Ethiopia & 2013 & $22.5 \%$ \\
\hline 12 & Sanjay Sharma et al., & India (Farrukhabad) & 2014 & $4 \%$ \\
\hline 13 & Pragati Chigurupati et al., & Eluru & 2014 & $23.5 \%$ \\
\hline 14 & Senevirathna et al., & Sri lanka & 2015 & $11.33 \%$ \\
\hline 15. & Present Study & Telangana & 2016 & $4 \%$ \\
\hline
\end{tabular}

Table.2 Gender wise distribution of HCV cases

\begin{tabular}{|c|c|c|c|c|}
\hline S. No & Author & Year & Place & Percentage \\
\hline 1. & Masroor A.Qazi et al., & 2006 & Pakistan & $\begin{array}{c}\text { Male- } 58.2 \% \\
\text { Female- } 42.8 \%\end{array}$ \\
\hline 3. & Abel Girma Ayele et al., & 2012 & Ethiopia & $\begin{array}{c}\text { Male- } 18.4 \% \\
\text { Female- } 29.5 \%\end{array}$ \\
\hline 4. & Subramanian vennila et al., & 2013 & Tamilnadu & $\begin{array}{c}\text { Male- } 59.6 \% \\
\text { Female- } 40.4 \%\end{array}$ \\
\hline 6 & Sanjay Sharma et al., & 2014 & Uttar Pradesh & $\begin{array}{c}\text { Male- } 65 \% \\
\text { Female- } 35 \%\end{array}$ \\
\hline 7 & Present Study & 2016 & Telangana & $\begin{array}{l}\text { Males- } 75 \% \\
\text { Females-25\% }\end{array}$ \\
\hline
\end{tabular}


Table.3 Age wise distribution of $\mathrm{HCV}$ cases

\begin{tabular}{|c|c|c|c|c|}
\hline S. No & Author & Place & Year & Prevalence \\
\hline 1. & Masroor A.Qazi et al., & Pakistan & 2006 & $\begin{array}{l}18-29 \operatorname{yrs}(26.5 \%) \\
30-39 y r s(35.7 \%) \\
40-75 y r s(37.8 \%)\end{array}$ \\
\hline 2. & Abel Girma Ayele et al., & Ethiopia & 2012 & $<50 \mathrm{yrs}$ \\
\hline 3. & $\begin{array}{l}\text { B.Vallab Ganesh } \\
\text { Bharadwaj } \text { et al., }\end{array}$ & South India & 2014 & $41-60 y r s$ \\
\hline 4. & Sajid Raza et al., & Bannu & 2014 & $\begin{array}{c}23-36 \mathrm{yrs}(5.55 \%) \\
15-17 \mathrm{yrs}(2.7 \%)\end{array}$ \\
\hline 5. & Sanjay Sharma et al., & Uttarpradesh & 2014 & $\begin{array}{l}60-70 y r s(7.2 \%) \\
50-60 y r s(6.3 \%) \\
30-40 y r s(5.9 \%)\end{array}$ \\
\hline 6 & Parveen Malhotra et al., & New Hub-Haryana & 2015 & $20-35 \mathrm{yrs}(38 \%)$ \\
\hline 7 & Present Study & Telangana & 2016 & 40-60Yrs \\
\hline
\end{tabular}

Table.4 Risk factors for $\mathrm{HCV}$

\begin{tabular}{|c|c|c|c|c|}
\hline S. No & Author & Place & Year & Percentage \\
\hline 1. & D.N. Amarapurkar et al., & Bombay & 1992 & $\begin{array}{c}\text { 38\% - Blood } \\
\text { transfusion }\end{array}$ \\
\hline 2. & $\begin{array}{l}\text { Beatriz Maria Garcia } \\
\text { Montalvo et al., }\end{array}$ & Mexico & 2008 & $\begin{array}{c}\text { Surgery- } 53.7 \% \\
\text { Blood transfusion- } \\
38.9 \%\end{array}$ \\
\hline 3. & Harmeet S. Rehan et al., & North India & 2011 & $\begin{array}{c}\text { 43.1\% Mutiple } \\
\text { injection exposure }\end{array}$ \\
\hline 4. & Anita Chakrtavarti et al., & New Delhi & 2011 & $\begin{array}{c}\text { Surgery- } 26.76 \% \\
\text { Blood transfusion- } \\
21.12 \%\end{array}$ \\
\hline 5 & Gupta Sonia et al., & Ludhiana & 2015 & $\begin{array}{l}1.45 \% \text { Blood } \\
\text { Donors }\end{array}$ \\
\hline 6 & Present Study & Telangana & 2016 & Surgery - $50 \%$ \\
\hline
\end{tabular}

Table.5 HCV antibody detection

\begin{tabular}{|c|c|c|c|c|}
\hline S. No & Author & Place & Year & Prevalence \\
\hline 1. & Chatterjee et al., & Calcutta & 2001 & $8.06 \%$ \\
\hline 2. & A Laraba et al., & Nigeria & 2009 & $14.4 \%$ \\
\hline 3. & Sanjay Sharma et al., & Uttarpradesh & 2014 & $4 \%$ \\
\hline 4. & D.B.Senevirathna et al., & Srilanka & 2015 & $11.33 \%$ \\
\hline 5. & Present study & Telangana & 2016 & $4 \%$ \\
\hline
\end{tabular}


In Present study, most common age group affected with HCV was 40-60Yrs similar to study from South India by (Vallab Ganesh Bharadwaj et al., 2014) who reported 4160 Yrs as commonly affected age group.

In Present study, surgery (50\%) was the major risk factors for HCV similar to a study from Mexico by Beatriz Maria Garcia et al., who reported that acquisition of $\mathrm{HCV}$ after Surgery was $53.7 \%$ (Table 4 and Fig. 5).

In Present study, HCV antibody was detected by ELISA in $4 \%$ of Chronic liver di sease cases correlating with a study from Uttarpradesh by (Sanjay Sharma et al., 2016) (Table 5).

In Present study, Prevalence of Hepatitis $\mathrm{C}$ in chronic liver disease cases was $4 \%$.

Prevalence of Hepatitis C was $75 \%$ among Males and 25\% among females

Hepatitis C infection was common in 40-60 Yrs of age group

The major risk factor associated with Hepatitis C infection among chronic liver disease patients was Surgery.

\section{Acknowledgement}

Authors are grateful to Manisha from Gandhi Hospital for her help and cooperation for the present investigation.

\section{References}

Arora, D. R., R. Sehgal, N. Gupta, A. Yadav, N. Mishra, S. B. Siwach. Prevalence of parenterally transmitted hepatitis viruses in clinically diagnosed cases of hepatitis, Indian j med microbiol. 2005 Jan; 23(1): 44-47
Beatriz María García-Montalvo; Pedro Luis Galguera-Colorado. Distribution of hepatitis $\mathrm{C}$ virus genotypes, risk factors and liver disease in patients from Yucatán, México. Annals of Hepatology 2008, 7(4): October -December: 345349.

Hanaa Ali Naem, and Prof. Hassan J. Hasony. Comparative study for various $\mathrm{HCV}$ Diagnostic methods used in Basrah health institutions International Journal of Scientific \& Engineering Research, Sept 2015; Volume 6, Issue 9.

Laraba, A, G Wadzali, B Sunday, O Abdulfatai, S Fatai. Hepatitis $C$ virus infection in Nigerians with chronic liver disease. The Internet Journal of Gastroenterology, 2009; Vol 9 Number 1.

Nirmala Poddar, Priya Ranjan Lenka, Nirupama Chayani, Sunil Mohanty, Bandana Mallick, Dipti Pattnaik. Seroprevalence of Hepatitis-C virus in blood donors and high risk individuals. journal of evolution of medical and dental sciences, Dec 2012; Vol 1, Issue 6.

Ramya S R, and Dr. Madhuri Kulkarni. Hepatitis C Virus- Epidemiology and Genotyping. IOSR Journal of Dental and Medical Sciences (IOSRJDMS).Volume 14, Issue 3 Ver. VIII (Mar. 2015), PP 29-34

Sanjay Sharma, Anil kumar Sharma, R. Sujatha and Asish Bansal. Risk factors of Hepatitis $\mathrm{C}$ infection in patients of chronic liver disease in a rural area of Uttar Pradesh. Indian J.Sci.Res. 7(1):193-196, 2016

Vallab Ganesh Bharadwaj, B., G. Vazhavandal, A. Uma and P. Chitra Rajalakshmi. Seroprevalence of Hepatitis C Virus Infection among Patients attending a rural teaching hospital in South India: A Three Year 
Study. Int.J.Curr.Microbiol.App.Sci (2014) 3(2): 123-127

Vardas E, Sitas F, Seidel K, Casteling A, Sim J. Prevalence of hepatitis C virus antibodies and genotypes in asymptomatic, first-time blood donors in Namibia. Bulletin of the World Health Organization. 1999; 77(12):965972.
Yao, Ermei, John E Tavis, and the Virahep-C Study Group. "A General Method for Nested RT-PCR Amplification and Sequencing the Complete HCV Genotype 1 Open Reading Frame." Virology Journal 2 (2005): 88.

\section{How to cite this article:}

Aliya Fatima and Nagamani, K. 2018. Prevalence of HCV Antibodies in Chronic Liver Disease Patients in Tertiary Care Hospital. Int.J.Curr.Microbiol.App.Sci. 7(10): 1312-1320.

doi: https://doi.org/10.20546/ijcmas.2018.710.147 